\title{
Production and sensitivity of bacteriocin-like activity among Porphyromonas gingivalis, Prevotella intermedia and Pr. nigrescens strains isolated from periodontal sites
}

\author{
R. TEANPAISAN, A. M. BAXTER* and C. W. I. DOUGLAS†
}

Department of Stomatology, Faculty of Dentistry, Prince of Songkhla University, Songkhla, Thailand and Departments of * Restorative Dentistry and †Oral Pathology, School of Clinical Dentistry, University of Sheffield, Sheffield S10 2TA

\begin{abstract}
The production of and sensitivity to bacteriocin-like activity among 44 strains of blackpigmented anaerobes isolated from periodontal sites were evaluated by both an overlay and an agar diffusion method. The species studied were Porphyromonas gingivalis, Prevotella intermedia and the closely related species Pr. nigrescens. Pr. intermedia strains $(\mathbf{9 0} \%)$ produced bacteriocin-like activity against $P r$. nigrescens and all $P r$. nigrescens were active against $P r$. intermedia. Both species showed a high degree of activity against $P$. gingivalis, whereas only one $P$. gingivalis strain produced bacteriocin-like activity against either of the other two species. Both $P r$. nigrescens and Pr. intermedia showed some activity $(40 \%$ and $20 \%$, respectively) against other strains of the same species. Such bacteriocin production might be expected to influence the distribution of these black-pigmented species in vivo. Of 224 periodontal sites sampled, only $2.6 \%$ yielded mixed cultures of black-pigmented species and of these only one strain, a $P$. gingivalis isolate, produced bacteriocin-like activity against any of the other strains isolated from these sites. These data support the concept that local production of bacteriocin-like activity in vivo may contribute to the selection of the black-pigmented bacterial profile in subgingival sites.
\end{abstract}

\section{Introduction}

Black-pigmenting, oral anaerobic bacteria have been associated with destructive forms of inflammatory periodontal disease. Of these bacteria, Porphyromonas gingivalis has been isolated frequently from advancing lesions and is thought to be the most virulent species [1]. Prevotella intermedia has also been found frequently in diseased sites of patients with chronic adult periodontitis, acute necrotising ulcerative gingivitis and pregnancy gingivitis [2]. However, some of the strains previously reported as Pr. intermedia may well have belonged to the closely related but newly described species, $P r$. nigrescens. These two species can be separated by serotyping [3-5], DNA-DNA hybridisation [6], 16S-RNA analysis [7], RAPD profiles [8] or total protein profiles on SDS-polyacrylamide gels $[9,10]$. Although recent studies with these methods have shown $\mathrm{Pr}$. nigrescens to be present at both

Received 30 Sept. 1997; revised version accepted 8 Dec. 1997.

Corresponding author: Dr C. W. I. Douglas. clinically diseased and healthy subgingival sites, the view is now generally held that the organism is associated with health rather than disease $[9,11,12]$. In contrast, $P$. gingivalis is rarely found in the oral cavity of healthy subjects $[9,13]$.

Despite black-pigmented anaerobes being found frequently in periodontal infections, recent studies have indicated that mixed populations of these organisms are relatively uncommon, suggesting that they may be incompatible $[9,14-16]$. Such incompatibility may be due either to competition between species for essential nutrients or to the production of aggressive compounds, such as bacteriocins. Similar incompatibility, which is due to bacteriocin production [17], has been described among strains of another putative periodontal pathogen, Actinobacillus actinomycetemcomitans, and between this and various commensal oral species [18].

Only limited information is available concerning bacteriocin production and sensitivity among blackpigmented anaerobes. A proteinaceous bacteriocin-like 
compound, called melanocin, has been isolated from a black-pigmented 'Bacteroides' strain - ' $B$ '. (now $P r$.) melaninogenicus $(a)$ [19] - and two separate bacteriocins have been isolated from ' $B$ '. (Pr.) intermedius $(a)$, one with activity against ' $B$ '. $(P$.) gingivalis and one against ' $B$ '. (Pr.) intermedius $(a)$ [20,21]. More recently, Hohne et al. [22] studied the bacteriocin production and activity of numerous black-pigmenting strains isolated from periodontal sites and showed that $\mathrm{Pr}$. intermedia was the dominant effector species. However, only a few indicator strains were used in the study and there is no information available on bacteriocin production by the new species, $P r$. nigrescens.

The aim of this study was to assess the production of and sensitivity to bacteriocin-like activity among clinical isolates of $P$. gingivalis, $P r$. intermedia and Pr. nigrescens and to determine whether such activity could explain the apparent incompatibility between black-pigmented anaerobes in periodontal sites.

\section{Materials and methods}

\section{Bacteria}

Forty-eight strains (4 reference strains and 44 clinical isolates) were examined for their bacteriocin production and sensitivity, comprising $P$. gingivalis (13), $P r$. intermedia (14) and Pr. nigrescens (21). The four reference strains used were $P$. gingivalis W50, $P r$. intermedia ATCC 25611 and Pr. nigrescens ATCC 25261 and MH11; the latter was provided by H.N. Shah, National Collection of Type Cultures, Central Public Health Laboratory, 61 Colindale Avenue, London.

Clinical strains were isolated from subgingival plaque obtained from diseased and healthy sites of 46 adult patients with a clinical diagnosis of adult periodontitis as described previously [9]. Samples were obtained with sterile paper points placed subgingivally for $10 \mathrm{~s}$ and cultured on Fastidious Anaerobe Agar (FAA; Lab M) supplemented with yeast extract $0.5 \%$ and horse blood (Oxoid) $8 \%$ in an atmosphere of $\mathrm{CO}_{2} 10 \%, \mathrm{H}_{2}$ $10 \%, \mathrm{~N}_{2} 80 \%$ in an anaerobic jar for 7-14 days. Collection and processing of samples were completed within $1 \mathrm{~h}$. Several colonies that were either uniformly black or showing the beginning of brown pigmentation were selected from each specimen and identified to species level by the methods described previously $[9,23]$.

\section{Bacteriocin production}

Bacteriocin-like activity was assessed by an agar overlay technique and by an agar diffusion method. In the overlay method, based on that originally described by Fredericq [24], several possible producer strains were stab-cultured on plates of FAA, anaerobi- cally for $24-48 \mathrm{~h}$. The plates were then exposed to UV light overnight under aerobic conditions to stop growth and all strains were re-streaked to check for their survival. Indicator strains were grown anaerobically for $24-48 \mathrm{~h}$ in BHI broth supplemented with haemin $5 \mu \mathrm{g} / \mathrm{ml}$, yeast extract $0.5 \%$ and vitamin $\mathrm{K} 1 \mu \mathrm{g} / \mathrm{ml}$. Cell suspensions $\left(0.5 \mathrm{ml}\right.$ adjusted to $\left.\mathrm{A}_{550} 1.5\right)$ were each added to $5 \mathrm{ml}$ of molten FAA and immediately poured on top of the plates of the producer strains. These were then incubated for $24 \mathrm{~h}$ at $37^{\circ} \mathrm{C}$ in anaerobic conditions and examined for the presence of zones of inhibition around the inoculae of the producer strains.

In the agar diffusion method, modified from that of Riley and Mee [25], filter membranes $(9 \mathrm{~cm}$ diameter, $0.45 \mu \mathrm{m}$ pore size; Schleicher and Schulle) were sterilised by exposure to UV light ( 30 min each side) and floated on molten FAA supplemented with horse blood $8 \%$ in petri dishes; after setting, the plates were dried. The total surface of each membrane was then inoculated with growth from a young plate culture of a possible producer strain and incubated at $37^{\circ} \mathrm{C}$ anaerobically. The membrane, with adherent growth, was then carefully removed with forceps and a thin layer of molten FAA plus blood $(5 \mathrm{ml})$ was pipetted on to the surface to replace any nutrient loss from the agar. After drying, the plates were inoculated with 5$\mu l$ of suspensions of indicator strains; up to 10 strains were placed on a single plate. Plates were then incubated anaerobically for up to 7 days and examined for growth of indicators. As a control in both methods, the producer strain was also included as an indicator strain.

\section{Results and discussion}

Initial tests with a 'cross-streak' method showed that most strains failed to grow on areas of agar that had previously supported growth of the homologous strain. This suggested that the original inoculum had significantly depleted the nutrients in the surface layer of the agar and that this lack of growth might be confused with bacteriocin production. To overcome this problem, two approaches were taken. In the first, organisms were suspended in a suitable nutrient agar overlay on the killed growth of the producer strains, while in the second approach, all growth of the original strain was removed and the plate was then overlaid with a thin layer of the same medium before strains were inoculated as spots. Both approaches gave satisfactory and similar results and are illustrated in Figs. 1 and 2.

Production of bacteriocin-like activity by strains of $P$. gingivalis, Pr. intermedia and Pr. nigrescens isolated as single species from clinical sites is shown in Table 1. The strains were tested against a selection of eight indicator strains comprising at least one reference strain and a range of clinical isolates chosen at 


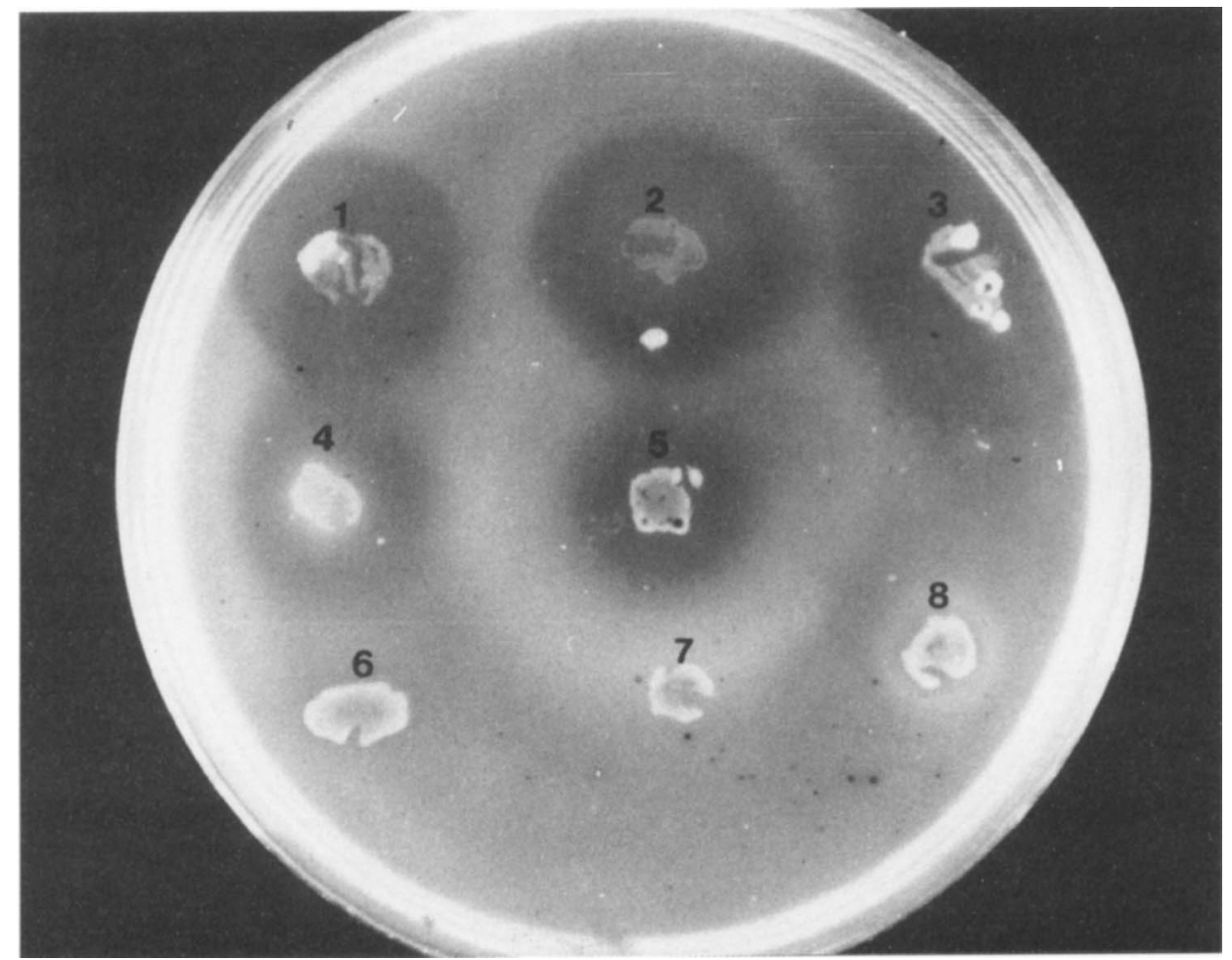

Fig. 1. Agar plate showing bacteriocin production by Pr. intermedia (1-3) and Pr. nigrescens (4-5) screened by incorporation of a $P$. gingivalis indicator strain in an agar overlay. Strains $6-8$ are not active.

random. Occasional strains were lost during the period of the study, which explains why not all strains were tested against all indicators. None of the $P$. gingivalis isolates tested produced activity against any $P r$. intermedia, $P r$. nigrescens or the other strains of $P$. gingivalis. This finding is similar to that reported by Hohne et al. [18] who showed that only a few strains of $P$. gingivalis showed activity against $P$. endodontalis and $P$. asaccharolytica and apparently none against $P r$. intermedia strains. Pr. nigrescens was not tested in that study. In contrast to $P$. gingivalis, most $P r$. intermedia and Pr. nigrescens strains produced bacteriocin-like activity; $90 \%$ of $P r$. intermedia strains showed activity against $P r$. nigrescens strains and all $P r$. nigrescens strains were active against $P r$. intermedia. The majority $(85 \%)$ of $P r$. nigrescens strains and $91 \%$ of $P r$. intermedia strains inhibited the $P$. gingivalis indicator strains. Furthermore, $20 \%$ of $P r$. intermedia and $40 \%$ of $P r$. nigrescens strains showed bacteriocin-like activity against other strains of the homologous species. These data show that production of bacteriocin-like activity is common among this group of black-pigmented anaerobes and is, therefore, in general agreement with the findings of other workers [19-22].

No attempt has been made in this study to establish that the inhibitory activity detected conformed to the criteria defining bacteriocins [26] because this would require purification of the active factor. However, the activity detected showed a limited spectrum, as do bacteriocins and it did not appear to be due to diffusable metabolites, such as acids, because the $\mathrm{pH}$ of the agar under the growth of a number of strains was approximately 7.5 .

The relevance of the bacteriocin-like activity described above for the ecology of black-pigmented anaerobes is currently unclear. However, if bacteriocin production in vivo is significant, mixtures of these three blackpigmented organisms in periodontal sites might be expected to be rare. Indeed, of the 224 periodontal sites sampled in 46 patients in this study, only six sites $(2.7 \%)$ yielded a mixture of black-pigmented species and all except one of these were from diseased periodontal sites. This finding is in accordance with those of others $[9,14-16]$, although one report differs from the findings of the present study [27]. This exception may have been due either to the method used to collect the specimens (e.g., paper point versus currette) or to the fact that, in the present study, only up to 13 colonies of black-pigmenting organisms from each sample were speciated and so organisms present in low numbers may have been missed. The mixtures obtained comprised $P$. gingivalis $+P r$. intermedia (one site), $P$. gingivalis $+P r$. nigrescens (two sites), $P$. gingivalis $+P$. denticola (one site), $P r$. intermedia + $P r$. nigrescens (one site) and Pr. nigrescens $+P r$. denticola (one site). All the Pr. nigrescens, $P$. gingivalis and $P r$. intermedia isolates were examined for production of bacteriocin-like activity against each other and with the exception of one $P$. gingivalis strain, none of the isolates produced inhibitory activity against any other strain. 

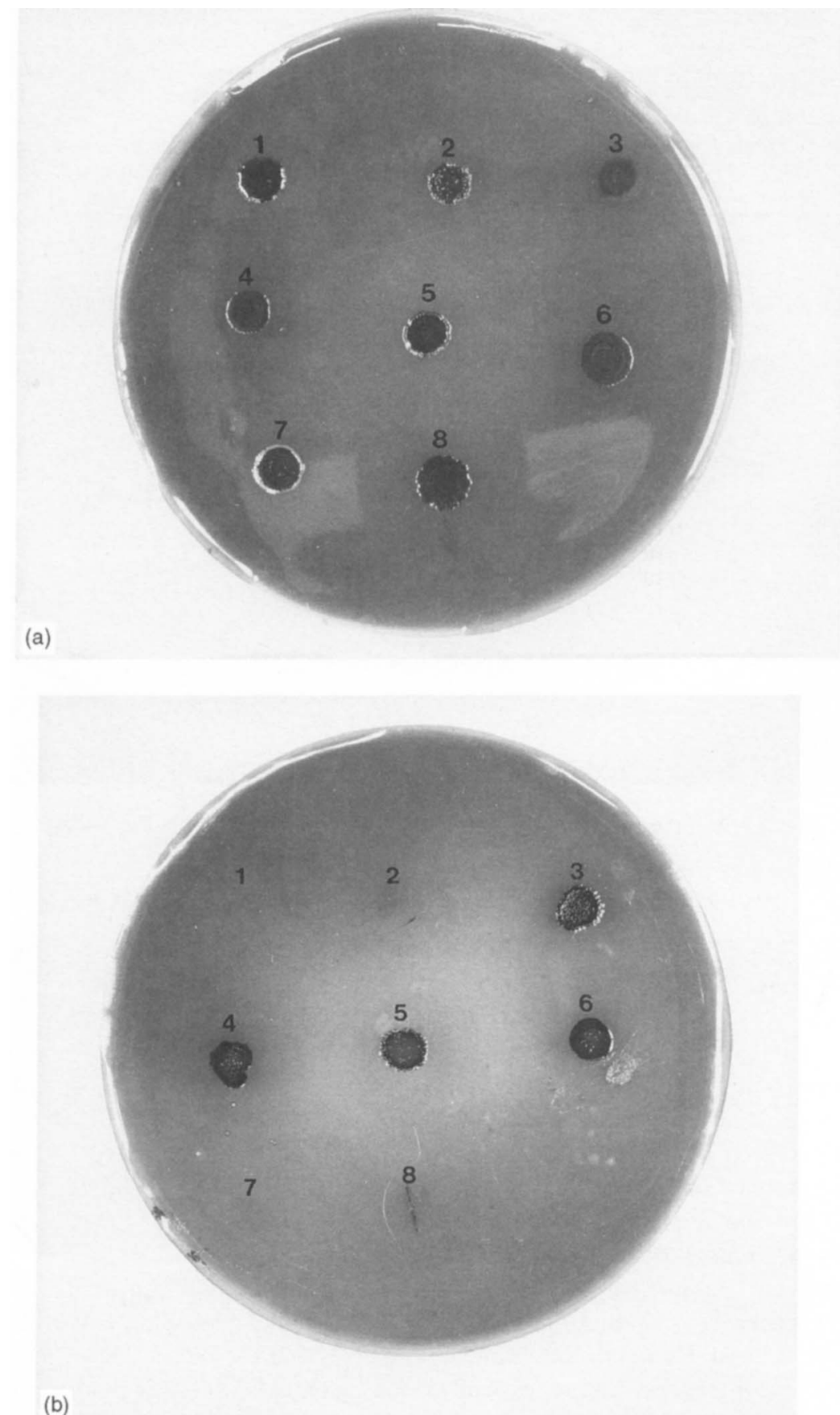

Fig. 2. (a) Control agar plate showing growth of $P r$. nigrescens indicator strains 1-8 and (b) test plate showing bacteriocin sensitivity of strains $1,2,7$ and 8 as illustrated by lack of growth. The Pr. nigrescens producer strain had been grown on a membrane filter on the agar surface, which was removed before inoculation of the indicator strains.

Although the numbers are small, this finding would support the concept that bacteriocin production by $\mathrm{Pr}$. intermedia and Pr. nigrescens is a significant factor in determining their distribution in periodontal sites. Nonetheless, as $P$. gingivalis was not found to produce bacteriocin activity in vitro, the question arises as to why any sites should harbour high levels of $P$. gingivalis but no significant numbers of Pr. intermedia or $P r$. nigrescens, as was found in $8.5 \%$ of sites by Teanpaisan et al. [23]. Perhaps this can be explained on the basis of the time at which species become established relative to each other, their nutrient requirements and the environment prevailing at that time. For example, $P$. gingivalis is known to have a higher affinity for haemin than Pr. intermedia [28] and so if $P$. gingivalis is present at a site first where haemin is available, any Pr. intermedia cells subsequently attempting to colonise might not be able to obtain enough haemin to proliferate sufficiently to generate a bacteriocin challenge. Consequently, although not producing bacteriocin activity, $P$. gingivalis may become the dominant black-pigmented species at some sites by virtue of its metabolic activity. In contrast, at sites where Pr. intermedia 
Table 1. Bacteriocin-like activity among $P$. gingivalis, Pr. intermedia and Pr. nigrescens strains isolated as the sole black-pigmented species from periodontal sites

\begin{tabular}{|c|c|c|c|}
\hline \multirow[b]{2}{*}{ Indicator strains ${ }^{*}$} & \multicolumn{3}{|c|}{$\begin{array}{c}\text { Number of producer strains/number } \\
\text { of strains tested }\end{array}$} \\
\hline & P. gingivalis & Pr. intermedia & Pr. nigrescens \\
\hline $\begin{array}{l}\text { P. gingivalis } \\
\text { W50 } \\
\text { strain } 1 \\
\text { strain } 2 \\
\text { strain } 3 \\
\text { strain } 4 \\
\text { strain } 5 \\
\text { strain } 6 \\
\text { strain } 7\end{array}$ & $\begin{array}{l}0 / 10 \\
0 / 10 \\
0 / 10 \\
0 / 10 \\
0 / 10 \\
0 / 10 \\
0 / 10 \\
0 / 10 \\
0 / 10\end{array}$ & $\begin{array}{l}11 / 12 \\
11 / 12 \\
11 / 12 \\
11 / 12 \\
11 / 12 \\
11 / 12 \\
11 / 12 \\
11 / 12 \\
11 / 12\end{array}$ & $\begin{array}{l}11 / 13 \\
11 / 13 \\
11 / 13 \\
11 / 13 \\
11 / 13 \\
11 / 13 \\
11 / 13 \\
11 / 13 \\
11 / 13\end{array}$ \\
\hline $\begin{array}{l}\text { Pr. intermedia } \\
25611 \\
\text { strain } 1 \\
\text { strain } 2 \\
\text { strain } 3 \\
\text { strain } 4 \\
\text { strain } 5 \\
\text { strain } 6 \\
\text { strain } 7\end{array}$ & $\begin{array}{l}0 / 10 \\
0 / 10 \\
0 / 10 \\
0 / 10 \\
0 / 10 \\
0 / 10 \\
0 / 10 \\
0 / 10\end{array}$ & $\begin{array}{l}2 / 10 \\
2 / 10 \\
2 / 10 \\
2 / 10 \\
2 / 10 \\
2 / 10 \\
2 / 10 \\
2 / 10\end{array}$ & $\begin{array}{l}18 / 18 \\
18 / 18 \\
18 / 18 \\
18 / 18 \\
18 / 18 \\
18 / 18 \\
18 / 18 \\
18 / 18\end{array}$ \\
\hline $\begin{array}{l}\text { Pr. nigrescens } \\
25261 \\
\text { MH 11 } \\
\text { strain 1 } \\
\text { strain 2 } \\
\text { strain } 3 \\
\text { strain } 4 \\
\text { strain } 5 \\
\text { strain } 6\end{array}$ & $\begin{array}{l}0 / 10 \\
0 / 10 \\
0 / 10 \\
0 / 10 \\
0 / 10 \\
0 / 10 \\
0 / 10 \\
0 / 10\end{array}$ & $\begin{array}{l}9 / 10 \\
9 / 10 \\
9 / 10 \\
9 / 10 \\
9 / 10 \\
9 / 10 \\
9 / 10 \\
9 / 10\end{array}$ & $\begin{array}{l}4 / 10 \\
4 / 10 \\
4 / 10 \\
4 / 10 \\
4 / 10 \\
4 / 10 \\
4 / 10 \\
4 / 10\end{array}$ \\
\hline
\end{tabular}

*Indicator organisms labelled as 'strain 1, 2, 3', etc. are clinical isolates; others are reference strains.

begins to grow first, production of bacteriocin-like activity could limit the proliferation of newly colonising $P$. gingivalis cells and consequently reduce the competition for nutrients faced by the resident $P r$. intermedia strains. At present, such an explanation is speculative and will require further work, perhaps with mixed chemostat cultures of organisms, to establish exactly how these three species interact so that one becomes dominant.

\section{References}

1. Zambon JJ, Grossi S, Dunford R, Haraszthy VI, Preus $H$ Genco RJ. Epidemiology of subgingival bacterial pathogens in periodontal disease. In: Genco $R$, Hamada $S$, Lehner $T$, McGhee J, Mergenhagen S (eds) Molecular pathogenesis of periodontal disease. Washington DC, ASM Press. 1994: 3-12.

2. Slots J, Listgarten MA. Bacteroides gingivalis, Bacteroides intermedius and Actinobacillus actinomycetemcomitans in human peridontal diseases. J Clin Periodontol 1988; 15: 85-93.

3. Gmür R, Guggenheim B. Antigenic heterogeneity of Bacteroides intermedius as recognized by monoclonal antibodies. Infect Immun 1983; 42: 459-470.

4. Gmür R, Wyss C. Monoclonal antibodies to characterize the antigenic heterogeneity of Bacteroides intermedius. In: Macario AJL, Conway de Macario E (eds) Monoclonal antibodies against bacteria, vol 1. London, Academic Press. 1985: 91-119.

5. Devine DA, Pearce MA, Gharbia SE, Shah HN, Dixon RA, Gmür R. Species-specificity of monoclonal antibodies recognising Prevotella intermedia and Prevotella nigrescens. FEMS
Microbiol Lett 1994; 120: 99-104.

6. Johnson JL, Holdeman LV. Bacteroides intermedius comb nov. and descriptions of Bacteroides corporis sp. nov. and Bacteroides levii sp.nov. Int J Syst Bacteriol 1983; 33: 15-25.

7. Milsom SE, Sprague SV, Dymock D, Weightman AJ, Wade WG. Rapid differentiation of Prevotella intermedia and Prevotella nigrescens by $16 \mathrm{~S}$ rDNA PCR-RFLP. $J \mathrm{Med}$ Microbiol 1996; 44: 41-43.

8. Matto J, Saarela M, von Troil-Linden B, Alaluusua S, Jousimies-Somer H, Asikainen S. Similarity of salivary and subgingival Prevotella intermedia and Prevotella nigrescens isolates by arbitrarily primed polymerase chain reaction. Oral Microbiol Immunol 1996; 11: 395-401.

9. Teanpaisan R, Douglas CWI, Walsh TF. Characterization of black-pigmented anaerobes isolated from diseased and healthy periodontal sites. J Periodont Res 1995; 30: 245-251.

10. Cookson AL, Wray A, Handley PS, Jacob AE. An investigation into the use of SDS-PAGE of cell surface extracts and proteolytic activity to differentiate Prevotella nigrescens and Prevotella intermedia. FEMS Microbiol Lett 1996; 136: $109-115$.

11. Moore WEC, Moore LVH, Ranney RR, Smibert RM, Burmeister JA, Schenkein HA. The microflora of periodontal sites showing active destructive progression. $J$ Clin Periodontol 1991; 18: 729-739.

12. Gharbia SE, Haapasalo M, Shah HN et al. Characterization of Prevotella intermedia and Prevotella nigrescens isolates from periodontic and endodontic infections. J Periodontol 1994; 65: $56-61$.

13. Zambon JJ, Reynolds HS, Slots J. Black-pigmented bacteroides spp. in the human oral cavity. Infect Immun 1981; 32: 198-203.

14. Loesche WJ, Syed SA, Schmidt E, Morrison EC. Bacterial profiles of subgingival plaques in periodontitis. $J$ Periodontol 1985; 56: 447-456.

15. Van Winkelhoff AJ, Van der Velden U, Clement M, De Graff J Intra-oral distribution of black-pigmented Bacteroides species in periodontitis patients. Oral Microbiol Immunol 1988; 3: $83-85$.

16. Torkko H, Asikainen S. Occurrence of Porphyromonas gingivalis with Prevotella intermedia in periodontal samples. FEMS Immunol Med Microbiol 1993; 6: 195-198.

17. Hammond BF, Lillard SE, Stevens RH. A bacteriocin of Actinobacillus actinomycetemcomitans. Infect Immun 1987; 55: 686-691.

18. Wolff LF, Liljemark WF, Bloomquist CG, Pihlstrom BL, Schaffer EM, Bandt C. The distribution of Actinobacillus actinomycetemcomitans in human plaque. J Periodont Res 1985; 20: $237-250$.

19. Nakamura T, Fujimura S, Obata N, Yamazaki N. Bacteriocinlike substance (melaninocin) from oral Bacteroides melaninogenicus. Infect Immun 1981; 31: 28-32.

20. Takada K, Hirasawa M, Ikeda T. Isolation and purification of bacteriocin from Prevotella intermedia (Bacteroides intermedia). J Periodontol 1991; 62: 439-444.

21. Hammond BF, Lillard SE, Stevens RH. A bacteriocin active against Bacteroides gingivalis and Bacteroides intermedius. $J$ Dent Res 1987; 66: 276.

22. Hohne C, Neumann D, Jentzsch M. Antimicrobial activities of black-pigmented gram-negative anaerobes. FEMS Immunol Med Microbiol 1993; 6: 235-240.

23. Teanpaisan R, Douglas CWI, Eley AR, Walsh TF. Clonality of Porphyromonas gingivalis, Prevotella intermedia and Prevotella nigrescens isolated from periodontally diseased and healthy sites. J Periodont Res 1996; 31: 423-432.

24. Fredericq P. Colicins. Annu Rev Microbiol 1957; 11: 7-22.

25. Riley TV, Mee BJ. Simple method for detecting Bacteroides spp. bacteriocin production. J Clin Microbiol 1981; 13: 594-595.

26. Tagg JR, Danjani AS, Wannamaker LW. Bacteriocins of grampositive bacteria. Bacteriol Rev 1976; 40: 722-756.

27. Torkko H, Asikainen S. Occurrence of Porphyromonas gingivalis with Prevotella intermedia in periodontal samples. FEMS Immunol Med Microbiol 1993; 6: 195-198.

28. Tompkins GR, Wood DP, Birchmeier KR. Detection and comparison of specific hemin binding by Porphyromonas gingivalis and Prevotella intermedia. J Bacteriol 1997; 179: 620-626. 